\title{
A giant left atrial thrombus
}

\author{
Aung Naing Lin, ${ }^{1}$ Sithu Lin, ${ }^{1}$ Kyawzaw Lin, ${ }^{1}$ Rahul Gokhroo ${ }^{2}$
}

'Department of Internal Medicine, Brooklyn Hospital Center, Brooklyn, New York, USA ${ }^{2}$ Department of Cardiology, Brooklyn Hospital Center, Brooklyn, New York, USA

Correspondence to Dr Sithu Lin,

dr.sithulin@gmail.com

Accepted 12 April 2017

\section{(1) \\ CrossMark}

\section{To cite: Lin AN, Lin $S$,} Lin K, et al. BMJ Case Rep Published Online First: [please include Day Month Year]. doi:10.1136/bcr-2017219792

\section{DESCRIPTION}

A 57-year-old woman with hypertension, dyslipidaemia, diabetes mellitus type 2, paroxysmal atrial fibrillation (AF), porcine mitral valve replacement and dilated cardiomyopathy requiring an automatic implantable cardioverter defibrillator presented with palpitation for 2 days. She had tiny left atrial thrombus (LAT), which resolved completely with warfarin 6 months ago. She was not in compliance with warfarin thereafter. Physical examination had no evidence for systemic embolisations and cardiovascular examination was unremarkable. ECG showed AF with rapid ventricular response of 132 beats per minutes. Chest X-ray showed remarkable cardiomegaly without congestion. Transthoracic echocardiogram (TTE) 6 months prior revealed a small LAT, normal bioprosthetic mitral valve and mild biventricular dilation with a severely reduced left ventricular ejection fraction of $25 \%-30 \%$. Repeated TTE exposed a giant LAT measuring $4 \mathrm{~cm}$ $\times 3.5 \mathrm{~cm}$ (figure $1 \mathrm{~A}-\mathrm{D}$, arrows). Surgical removal was recommended due to high risk of embolisation but patient deferred. Enoxaprin overlapping with warfarin was initiated and a rapid reduction in the size of the LAT was observed in 2 weeks.

Intracardiac thrombi are clinical dilemma because of systemic complications and lack of evidence-based guidelines in selecting optimal therapies. Clinical decisions and recommendations for primary and secondary prevention of embolic manifestations depend on echocardiography findings. TTE is generally recommended for detecting ventricular thrombus, whereas TEE is ideal for the atrial thrombus. ${ }^{1}$ Although various options for the management of intracardiac thrombi including anticoagulation, thrombolytic and interventions either endovascular or open surgery exist, anticoagulation is still effective as first-line therapy. There is little evidence of either in favour or against aggressive management when there is failure of medical management. ${ }^{23}$ More clinical studies are needed for development of proper guidelines. Therefore, anticoagulation alone is effective for a giant LAT and selection of treatment needs to be individualised.

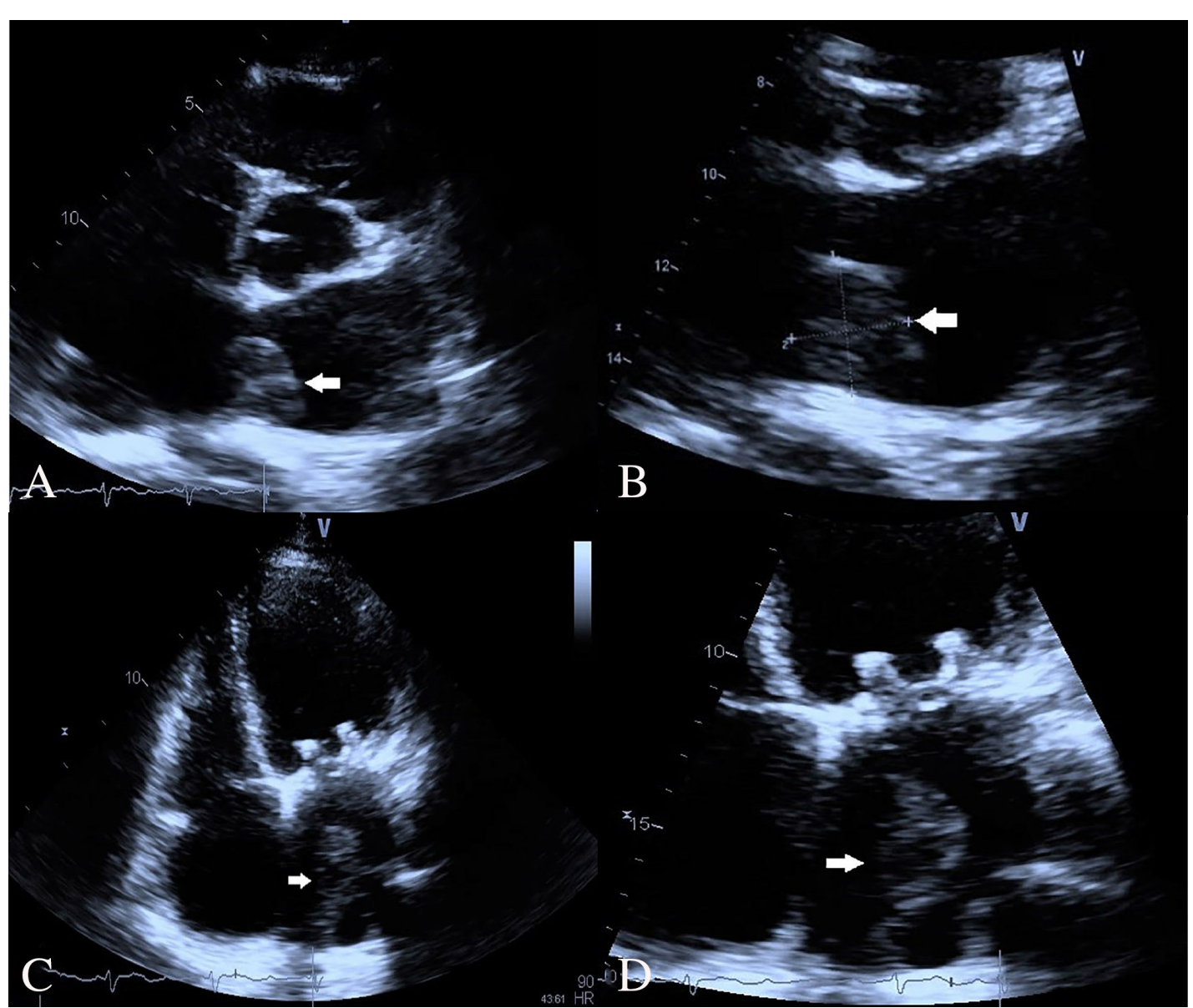

Figure 1 Two-dimensional transthoracic echocardiography showing a giant thrombus (white arrows) in (A) parasternal long axis, (B) focus parasternal long axis, (C) apical four chambers and (D) focus apical four-chambers view. 


\section{Learning points}

- Giant atrial thrombus (AT) can easily be detected by transthoracic echocardiography.

- Regardless of the size, anticoagulation alone is effective for a giant left AT.

- Selection of a management option should be individualised.

Contributors ANL was involved in conception of the idea, manuscript preparation, assay analysis, interpretation and proof reading. SL, KL and RG were involved in conception of the idea, assay analysis, patient care and proof reading. All the authors approved the submitted manuscript.

Competing interests None declared.
Patient consent Obtained.

Provenance and peer review Not commissioned; externally peer reviewed.

(c) BMJ Publishing Group Ltd (unless otherwise stated in the text of the article) 2017. All rights reserved. No commercial use is permitted unless otherwise expressly granted.

\section{REFERENCES}

1 Turhan S, Ozcan OU, Erol C. Imaging of intracardiac thrombus. Cor Vasa 2013;55:e176-e183.

2 Kristiansen A, Brandt L, Agoritsas T, et al. Applying new strategies for the national adaptation, updating, and dissemination of trustworthy guidelines: results from the norwegian adaptation of the antithrombotic therapy and the prevention of thrombosis, 9th ed: american college of chest physicians Evidence-Based clinical practice guidelines. Chest 2014;146:735-61.

3 Egolum UO, Stover DG, Anthony R, et al. Intracardiac Thrombus: diagnosis, complications and management. Am J Med Sci 2013;345:391-5.

Copyright 2017 BMJ Publishing Group. All rights reserved. For permission to reuse any of this content visit http://group.bmj.com/group/rights-licensing/permissions.

BMJ Case Report Fellows may re-use this article for personal use and teaching without any further permission.

Become a Fellow of BMJ Case Reports today and you can:

- Submit as many cases as you like

- Enjoy fast sympathetic peer review and rapid publication of accepted articles

- Access all the published articles

- Re-use any of the published material for personal use and teaching without further permission

For information on Institutional Fellowships contact consortiasales@bmjgroup.com

Visit casereports.bmj.com for more articles like this and to become a Fellow 